\title{
Peningatan Keterampilan Menulis Paragraf Argumentasi Menggunakan Model Cooperative Think Pair Share Pada Siswa Kelas X C SMA Negeri 5 Singkawang
}

\author{
Elsa Lestari ${ }^{1)}$, Wahyuni Oktavia ${ }^{2)}$ \\ 1) STKIP Singkawang, Singkawang, Indonesia \\ E-mail: elsalestari17494@gmail.com \\ ${ }^{2)}$ STKIP Singkawang, Jl. STKIP Kelurahan Naram, Singkawang, Indonesia \\ E-mail: oktaviawahyuni9@gmail.com.
}

\begin{abstract}
Abstrak. Penelitian ini dilatarbelakangi oleh rendahnya nilai menulis siswa. Hal ini dikarenakan kegiatan menulis merupakan kegiatan yang sulit dan memerlukan latihan yang terus menerus, siswa kurang termotivasi dalam pembelajaran menulis sehingga siswa kurang terampil dalam mengungkapkan isi pikirannya ke dalam bentuk tulisan dan menghasilakan tulisan yang baik. Penelitian ini difokuskan pada materi menulis paragraf argumentasi menggunakan model cooperative think pair share. Berdasarkan uraian di atas, rumusan masalah dalam peneltian ini adalah bagaimanakah perencanaan, pelaksanaan dan hasil pembelajaran menulis paragraf argumentasi menggunakan model coperative think pair share. Metode penelitian ini adalah deskriptif dengan bentuk kualitatif. Penelitian ini dilakasankan 2 siklus, setiap siklusnya dilakukan 2 kali pertemuan. Prosedur pelaksanaan penelitian ini terdiri dari perencanaan, tindakan, pengamatan, dan refleksi hasil kegiatan. Penerapan model pembelajaran cooperative think pair share dalam penelitian tindakan kelas dapat meningkatkan proses pembelajaran menulis paragraf argumentasi. Hal ini dibuktikan dengan peningkatan kemampuan guru dalam mengelola pembelajaran, dan kegiatan dalam partisipasi siswa mengikuti proses pemebelajaran. Perencanaan pembelajaran meningkat dari 72,63\% pada siklus I menjadi 83,15\% pada siklus II. Pelaksanaan pembelajaran meningkat dari 76,59\% pada siklus I menjadi 84,25\% pada siklus II. Peningkatan hasil belajar siswa dapat diketahui setelah membandingkan hasil pra tindakan siklus I dan siklus II. Nilai rata-rata yang diperoleh siswa sebelum adanya tindakan adalah $61,42 \%$. Pada siklus I rata-rata nilai $67,38 \%$ dengan persentase ketuntasan sebesar $66,66 \%$ dan pada siklus II nilai rata-rata 74,28\% dengan persentase ketuntasan sebesar $80,95 \%$ mencapai pada peningkatan yang diharapkan.
\end{abstract}

Kata Kunci: Keterampilan Menulis, Cooperative Think Pair Share.

\section{PENDAHULUAN}

Bahasa merupakan alat komunikasi yang digunakan manusia. Pengajaran bahasa khususnya bahasa Indonesia bertujuan agar siswa terampil berbahasa dan mampu berkomunikasi baik secara tulisan maupun lisan dengan baik dan benar. Pelajaran bahasa Indonesia lebih ditekankan pada keterampilan. Pembelajaran keterampilan berbahasa Indonesia mencakup keterampilan menyimak, berbicara, membaca, dan menulis[10]. Keterampilan menulis merupakan keterampilan terakhir yang diperoleh siswa dan harus dikuasai siswa. Menulis sangat penting bagi pendidikan karena dapat menolong penulis berpikir secara kritis, dan dapat memperdalam daya tanggap dan persepsi, memecahkan masalah yang dihadapi dan menjelaskan pikiran-pikiran penulis.

Berdasarkan hasil praobservasi yang telah dilakukan, kualitas pembelajaran menulis paragraf argumentasi di kelas X C SMA Negeri 5 Singkawang masih rendah. Hal ini disebabkan oleh metode yang digunakan guru dalam pembelajaran kurang bervariasi. Selain itu, pembelajaran menulis paragraf argumentasi masih menggunakan metode ceramah, guru menjelaskan materi tentang materi paragraf argumentasi. Hal ini membuat peserta didik kurang aktif dan cendrung pasif dalam mengikuti proses pembelajaran. Siti Narulia, S.Pd. selaku guru mata pelajaran bahasa dan sastra Indonesia di kelas X SMA Negeri 5 Singkawang menjelaskan bahwa hasil belajar siswa dalam menulis pada kelas X A mencapai ketuntasan 52,17\%, kelas X B 43,47\%, dan kelas X C 38,09\% dari nilai kriteria ketutasan minimum yang ditentukan sekolah yaitu 70. Jika dilihat dari hasil belajar siswa pada tiap kelas, maka kelas X C merupakan kelas terendah dalam pencapaian hasil belajar.

Upaya yang dapat dilakukan adalah dengan mengubah metode pembelajaran yang digunakan oleh guru dengan lebih meningkatkan keikutsertaan siswa dalam proses pembelajaran yaitu dengan menerapakan model cooperative think pair share. Melalui penerapan model cooperative think pair share diharapkan siswa dapat meningkatkan 
keterampilan menulis paragraf argumentasi, mencipatkan suasana kelas dan suasana belajar aktif dan dapat memecahkan masalah baik secara individu maupun kelompok.

Berdasarkan latar belakang yang dikemukakan di atas, maka masalah umum "Bagaimana peningkatan keterampilan menulis paragraf argumentasi menggunakan model cooperative think pair share pada Siswa Kelas X C SMA Negeri 5 Singkawang?". Adapun sub-sub masalah yang akan dirumuskan dalam penelitian ini adalah (1) Bagaimanakah perencanaan pembelajaran keterampilan menulis paragraf argumentasi menggunakan model coopertaive think pair share pada siswa kelas X C SMA Negeri 5 Singkawang? (2) Bagaimanakah pelaksanaan pembelajaran keterampilan menulis paragraf argumentasi menggunakan model cooperative think pair share pada siswa kelas X C SMA Negeri 5 Singkawang? (3) Bagaimanakah hasil pembelajaran keterampilan menulis paragraf argumentasi menggunakan model cooperative think pair share pada siswa kelas X C SMA Negeri 5 Singkawang?. Tujuan penelitian ini adalah (1) Mendeskripsikan perencanaan pembelajaran menulis paragraf argumentasi menggunakan model cooperative think pair share pada siswa kelas X C SMA Negeri 5 Singkawang. (2) Mendeskripsikan pelaksanaan pembelajaran menulis paragraf argumentasi menggunakan model cooperative think pair share pada siswa kelas X C SMA Negeri 5 Singkawang. (3) Mendeskripsikan hasil belajar pembelajaran menulis paragraf argumentasi menggunakan model cooperative think pair share pada siswa kelas X C SMA Negeri 5 Singkawang.

[10] yang mengemukakan bahwa "Menulis merupakan suatu keterampilan berbahasa yang dipergunakan untuk berkomunikasi secara tidak langsung, tidak secara tatap muka dengan orang lain". Menulis merupakan salah satu keterampilan berbahasa yang digunakan untuk mengungkapkan pikiran atau gagasan dan untuk menyampaikan pesan (komunikasi) melalui bahasa tulis sebagai alat atau medianya, sehingga mudah untuk dipahami oleh pembaca. Keterampilan menulis merupakan keterampilan yang dianggap paling sulit untuk dikuasai penutur asli dikarenakan kemampuan menulis menghendaki penguasaan berbagai unsur kebahasaan dan unsur di luar bahasa yang sesuai dengan isi tulisan. Kedua unsur tersebut harus terjalin dengan baik untuk mengahasilkan karangan yang runtut dan padu [7]. Dapat juga diartikan bahwa menulis adalah berkomunikasi mengungkapkan pikiran, perasaan, dan kehendak kepada orang lain secara tertulis [9]

[6] mengemukakan paragraf adalah keseluruhan rangkaian kegiatan seseorang mengungkapkan gagasan dan menyampaikannya melalui bahasa tulis kepada pembaca untuk dipahami. Paragraf argumentasi adalah paragraf yang di dalamnya dikemukakan alasan atau argumen yang kuat untuk memperkuat ataupun menolak suatu pendapat, pendirian, atau gagasan [5]. Sedangkan [1] mengungkapkan argumentasi adalah ragam wacana yang dimaksudkan untuk mayakinkan pembacanya mengenai kebenaran yang disampaikan oleh penulis. Karangan argumentasi adalah karangan yang bertujuan meyakinkan pembaca agar menerima atau mengambil suatu doktrin, sikap, dan tingkah laku tertentu [3].

Model pembelajaran kooperatif merupakan suatu model pembelajaran yang mengutamakan adanya kelompokkelompok [4]. Setiap siswa dalam kelompok mempunyai tingkat kemampuan yang berbeda-beda (tinggi, sedang dan rendah) dan jika memungkinkan anggota kelompok berasal dari ras, budaya, suku yang berbeda serta memperhatikan kesetaraan gender.

Model think pair share atau berpikir berpasangan berbagi adalah merupakan jenis pembelajaran kooperatif yang dirancang untuk mempengaruhi pola interaksi siswa.[8] "Model pembelajaran ini tergolong tipe cooperative sintak: guru menyajikan materi klasikal, berikan persoalan kepada siswa dan siswa berkerja kelompok dengan cara berpasangan sebangku-sebangku (Think Pair), presentasi kelompok (Share), kuis individual, buat skor perkembangan tiap siswa, umumkan hasil kuis dan beri reward". Model pembelajaran think pair share diharapkan bisa mengubah sifat positif misalnya meningkatkan keaktifan dalam pembelajaran karena peserta didik tidak berkerja sendiri melainkan berkerja sama dengan pasanganya.

\section{METODE}

Tempat atau lokasi penelitian tindakan kelas ini dilaksanakan di SMA Negeri 5 Singkawang untuk mata pelajaran bahasa Indonesia kelas X C. Penelitian ini dilaksanakan pada tanggal 10 Februari 2016 untuk siklus I pertemuan pertama dan 15 Februari 2016 untuk siklus I pertemuan kedua, sedangkan siklus II dilaksanakan pada tanggal 17 Februari 2016 pada pertemuan pertama dan 19 Februari 2016 untuk pertemuan kedua. Kolaborator dalam penelitian ini adalah guru mata pelajaran bahasa Indonesia yang mengajar di kelas X C bernama Siti Narulia, S.Pd. Metode dalam penelitian ini menggunakan metode deskriptif. Metode penelitian deskriptif merupakan metode yang dimaksudkan untuk mengumpulkan informasi atau data tentang fenomena yang diteliti, misalnya kondisi sesuatu atau kejadian, disertai dengan informasi tentang faktor penyebab sehingga muncul kejadian yang dideskripsikan secara rinci, urut, dan jujur[2].

Bentuk penelitian yang digunakan dalam penelitian ini adalah kualitatif dan kuantitatif. Rancangan penelitian ini menggunakan penelitian tindakan kelas. Sumber data dalam penelitian ini adalah guru, siswa dan dokumen atau arsip. Adapun data yang diperoleh dalam penelitian ini adalah penilaian proses dan hasil. Teknik pengumpul data merupakan suatu cara yang dilakukan peneliti untuk memperoleh data. Tanpa mengetahui teknik pengumpul data, maka peneliti tidak akan mendapatkan data yang memenuhi standar data yang di terapkan". Untuk memperoleh data dalam penelitian ini, peneliti menggunakan teknik pengumpul sebagai berikut. (1) Teknik Observasi, (2) Teknik Pengukuran. Alat pengumpul data yang digunakan dalam penelitian ini adalah panduan observasi dan tes. Teknik analisis data yang digunakan dalam rencana penelitian ini adalah teknik deskriptif komparatif dan teknik 
analisis kritis yaitu perencanaan dinilai menggunakan APKG 1, pelaksanaan dinilai menggunakan APKG 2, dan hasil pembelajaran dianalisis dengan melakukan penilaian proses dan hasil.

\section{HASIL DAN PEMBAHASAN}

HASIL

\section{Deskripsi Hasil Penelitian}

a. Deskripsi Hasil Penelitin Siklus I

1) Perencanaan Keterampilan Menulis Paragraf Argumentasi Menggunakan Model Cooperative Think Pair Share

Pada tahap perencanaan dalam kegiatan pembelajaran menulis paragraf argumentasi peneliti dan kolaborator saling bekerja sama untuk menyusun kegiatan proses belajar mengajar yang akan dilaksanakan pada tanggal 10 dan 15 Februari 2016. Pada tahap ini peneliti dan kolaborator merencanakan kegiatan pembelajaran.

2) Pelaksanaan Pembelajaran Menulis Paragraf Argumentasi Menggunakan Model Coopertive Think Pair Share

a) Perencanaan (Planning)

Pada tahap perencanaan siklus I yang dilaksanakan pada tanggal 1 Februari 2016 peneliti dan kolaborator merencanakan pelaksanaan pembelajaran yang akan dilaksanakan ketika proses pembelajaran yaitu dengan Rencana Pelaksanaan Pembelajaran (RPP) yang meliputi merencanakan bahan ajar dan merumuskan tujuan, merencanakan pengorganisasian materi ajar, merencanakan skenario langkah-langkah pembelajaran, memilih sumber dan media, merencanakan evaluasi pembelajaran.

b) Tindakan (Acting)

Pada tahap pelaksanaan siklus I pertemuan pertama dilaksanakan hari Rabu tanggal 10 Februari 2016, dengan alokasi waktu yang digunakan $2 \times 45$ menit. Pertemuan kedua dilaksanakan pada hari Senin tanggal 15 Februari 2016, dengan alokasi waktu yang digunakan $2 \times 45$ menit.

c) Pengamatan (Observing)

(1) Pengamatan Terhadap Kemampuan Guru

Merencanakan Pembelajaran

Setelah peneliti melakukan pengamatan terhadap perencanaan penelitian pembelajaran dan menilai perencanaan pembelajaran yang dilakukan dari 19 aspek terdapat 4 aspek dengan kriteria sangat baik, 6 aspek dengan kriteria baik, 7 aspek dengan kriteria cukup, dan 2 aspek dengan kriteria kurang baik. Berdasarkan keterangan di atas, maka persentase yang diperoleh pada tahap perencanaan pembelajaran siklus 1 adalah 72,63\% (baik).

(2) Pengamatan Terhadap Kemampuan Guru Melaksanakan Pembelajaran

Setelah peneliti melakukan pengamatan pembelajaran di dalam kelas dan menilai pelaksanaan pembelajaran dari 25 aspek untuk pertemuan pertama terdapat 11 aspek dengan kriteria sangat baik, 4 aspek kriteria baik, terdapat 6 aspek dengan kriteria cukup, dan terdapat 4 aspek dengan kriteria kurang baik. Persentase yang dicapai dalam kegiatan pelaksanaan pembelajaran siklus 1 pertemuan pertama adalah $77,6 \%$ (baik). Selanjutnya 22 aspek untuk pertemuan kedua, terdapat 5 aspek dengan kriteria sangat baik, 7 aspek kriteria baik, dan terdapat 10 aspek dengan kriteria cukup baik. Persentase yang dicapai dalam kegiatan pelaksanaan pembelajaran siklus 1 pertemuan kedua adalah $75,45 \%$ (baik).

(3) Pengamatan Terhadap Aktivitas Siswa

Pada kategori sangat aktif secara keseluruhan di siklus I dengan jumlah 0\%. Pada kategori aktif secara keseluruhan di siklus I dengan jumlah 42,77\%. Pada ketegori cukup aktif secara keseluruhan di siklus I dengan jumlah 33,33\%. Pada ketegori kurang aktif secara keseluruhan di siklus I dengan jumlah $23,80 \%$. Pada ketegori tidak aktif secara keseluruhan di siklus I dengan jumlah $0 \%$.

(4) Pengamatan Terhadap Sikap Siswa

Pada kategori sangat baik secara keseluruhan di siklus I dengan jumlah 6,34\%. Pada kategori baik secara keseluruhan di siklus I dengan jumlah 47,61\%. Pada ketegori cukup baik secara keseluruhan di siklus I dengan jumlah 34,92\%. Pada ketegori kurang baik secara keseluruhan di siklus I dengan jumlah $11.11 \%$. Pada ketegori tidak baik secara keseluruhan di siklus I dengan jumlah $0 \%$.

d) Refleksi (Reflecting)

(1) Refleksi Terhadap Tahap Perencanaan

Dalam rencana pelaksanaan pembelajaran (RPP), sebagian besar aspek yang dinilai sudah mencapai kategori baik namun masih ada hal-hal yang perlu diperbaiki seperti berikut. (a) Kurangnya pemilihan materi pembelajaran yang sesuai dengan karakteristik siswa.

(2) Refleksi Terhadap Tahap Pelaksanaan

Refleksi terhadap tahap pelaksanaan dalam rencana pelaksanaan pembelajaran (RPP), sebagian besar aspek yang dinilai sudah mencapai kategori baik namun masih ada hal-hal yang harus diperbaiki sebagai berikut. (a) Guru kurang memberikan motivasi belajar kepada siswa, (b) Guru tidak melakukan tanya jawab dengan siswa mengenai materi pembelajaran yang telah dipelajari sebelumnya.

(3) Refleksi Terhadap Aktivitas Siswa

Sebagian besar aspek yang dinilai sudah tercapai namun masih ada beberapa aspek yang dinilai yang tidak dilakukan siswa dengan baik seperti (a) siswa berdiskusi dengan pasangannya untuk menyatukan pendapat mengenai permasalahan yang dibahas, (b) tiap pasangan menyiapkan laporan hasil diskusinya, (c) siswa lain memperhatikan temannya yang sedang presentasi.

(4) Refleksi Terhadap Sikap Siswa 
Refleksi terhadap sikap siswa sebagian besar aspek yang dinilai sudah mencapai kategori baik namun siswa masih kurang bersungguh-sunggguh dalam melaksanakan kegiatan pembelajaran sehingga berpengaruh terhadap hasil belajar siswa.

3) Hasil Menulis Paragraf Argumentasi Menggunakan Model Cooperative Think Pair Share

Pada hasil proses pembelajaran menulis paragraf argumentasi untuk siklus I terdapat 7 siswa $(33,34 \%)$ yang masih belum tuntas terdiri dari 2 siswa $(9,53 \%)$ dengan rentang nilai antara 40,0-54,9 dan 5 siswa $(23,81 \%)$ dengan rentang nilai antara 55,0-69,9, kemudian $14(66,66 \%)$ siswa yang tuntas dengan rentang nilai 70,0-84,5. Agar lebih jelas dapat dilihat pada tabel 1 sebagai berikut.

\section{TABEL 1}

\begin{tabular}{cccc}
\hline Nilai & Jumlah siswa & Pencapaian & $\%$ \\
\hline $0-39,9$ & 0 & Tidak tuntas & $0 \%$ \\
$40,0-54,9$ & 2 & Tidak tuntas & $9,53 \%$ \\
$55,0-69,9$ & 5 & Tidak tuntas & $23,81 \%$ \\
$70,0-84,5$ & 14 & Tuntas & $66,66 \%$ \\
$85,0-100$ & 0 & Tuntas & $0 \%$ \\
Jumlah & 21 & & $100 \%$ \\
\hline
\end{tabular}

b. Deskripsi Hasil Penelitian Siklus 2

1) Perencanaan Keterampilan Menulis Paragraf Argumentasi Menggunakan Model Cooperative Think Pair Share

Pada tahap perencanaan dalam kegiatan pembelajaran menulis paragraf argumentasi peneliti dan kolaborator saling bekerja sama untuk menyusun kegiatan proses belajar mengajar yang akan dilaksanakan pada tanggal 22 dan 24 Februari 2016. Pada tahap ini peneliti dan kolaborator merencanakan kegiatan pembelajaran.

2) Pelaksanaan Pembelajaran Menulis Paragraf Argumentasi Menggunakan Model Coopertive Think Pair Share

a) Perencanaan (Planning)

Pada tahap perencanaan siklus II yang akan dilaksanakan pada tanggal 20 Februari 2016, peneliti dan kolaborator merencanakan pelaksanaan pembelajaran yang akan dilaksanakan ketika proses pembelajaran yaitu dengan Rencana Pelaksanaan Pembelajaran (RPP) yang meliputi merencanakan bahan pembelajaran dan merumuskan tujuan, merencanakan pengorganisasian materi ajar, merencanakan skenario langkah-langkah pembelajaran, memilih sumber dan media pembelajaran, merencanakan evaluasi pembelajaran.

b) Tindakan (Acting)

Pada tahap pelaksanaan siklus II pertemuan pertama dilaksanakan hari Senin tanggal 22 Februari 2016, dengan alokasi waktu yang digunakan $2 \times 45$ menit. Pertemuan kedua dilaksanakan pada hari Rabu tanggal 24 Februari 2016, dengan alokasi waktu yang digunakan $2 \times 45$ menit.

c) Pengamatan (Observing)

(1) Pengamatan Terhadap Kemampuan Guru Merencanakan Pembelajaran
Setelah peneliti melakukan pengamatan terhadap perencanaan penelitian pembelajaran dan menilai perencanaan pembelajaran yang dilakukan dari 19 aspek terdapat 8 aspek dengan kriteria sangat baik, 6 aspek dengan kriteria baik, dan 5 aspek dengan kriteria cukup. Berdasarkan keterangan di atas, maka persentase yang diperoleh pada tahap perencanaan pembelajaran siklus 1 adalah $83,15 \%$ (baik).

(2) Pengamatan Terhadap Kemampuan Guru Melaksanakan Pembelajaran

Setelah peneliti melakukan pengamatan pembelajaran di dalam kelas dan menilai pelaksanaan pembelajaran dari 25 aspek untuk pertemuan pertama terdapat 12 aspek dengan kriteria sangat baik, 7 aspek kriteria baik, dan 6 aspek dengan kriteria cukup baik. Persentase yang dicapai dalam kegiatan pelaksanaan pembelajaran siklus II pertemuan pertama adalah $84,8 \%$ (baik). Selanjutnya 22 aspek untuk pertemuan kedua, terdapat 9 aspek dengan kriteria sangat baik, 8 aspek kriteria baik, dan 5 aspek dengan kriteria cukup baik. Persentase yang dicapai dalam kegiatan pelaksanaan pembelajaran siklus II pertemuan kedua adalah 83,63\% (baik).

(3) Pengamatan Terhadap Aktivitas Siswa

Pada kategori sangat aktif secara keseluruhan di siklus II dengan jumlah 19,04\%. Pada kategori aktif secara keseluruhan di siklus II dengan jumlah 47,62\%. Pada ketegori cukup aktif secara keseluruhan di siklus II dengan jumlah 14,29\%. Pada ketegori kurang aktif secara keseluruhan di siklus II dengan jumlah 19,05\%. Pada ketegori tidak aktif secara keseluruhan di siklus I dengan jumlah $0 \%$.

(4) Pengamatan Terhadap Sikap Siswa

Pada kategori sangat baik secara keseluruhan di siklus II dengan jumlah 7,94\%. Pada kategori baik secara keseluruhan di siklus II dengan jumlah 50,79\%. Pada ketegori cukup baik secara keseluruhan di siklus II dengan jumlah 34,92\%. Pada ketegori kurang baik secara keseluruhan di siklus II dengan jumlah 6,35\%. Pada ketegori tidak baik secara keseluruhan di siklus I dengan jumlah $0 \%$.

d) Refleksi (Reflecting)

(1) Refleksi Terhadap Tahap Perencanaan

Dalam rencana pelaksanaan pembelajaran (RPP), sebagian besar aspek yang dinilai sudah mencapai kategori sangat baik.

(2) Refleksi Terhadap Tahap Pelaksanaan

Dalam rencana pelaksanaan pembelajaran (RPP), sebagian besar aspek yang dinilai sudah mencapai kategori sangat baik.

(3) Refleksi Terhadap Aktivitas Siswa

Sebagian besar aktivitas siswa selama pembelajaran menggunakan model cooperative think pair share berlangsung sudah mencapai kategori baik.

(4) Refleksi Terhadap Sikap Siswa

Refleksi terhadap sikap siswa sebagian besar aspek yang dinilai sudah mencapai kategori baik.

3) Hasil Menulis Paragraf Argumentasi Menggunakan Model Cooperative Think Pair Share 
Pada hasil proses pembelajaran menulis paragraf argumentasi untuk siklus II terdapat 4 siswa $(19,05 \%)$ yang masih belum tuntas dengan rentang nilai antara $55,0-69,9$, kemudian $17(80,95 \%)$ siswa yang tuntas terdiri dari 11 siswa $(52,38 \%)$ dengan rentang nilai 70,0-84,5 dan tediri dari 6 siswa $(28,57 \%)$ dengan rentang nilai 85,0-100. Agar lebih jelas dapat dilihat pada tabel 2 sebagai berikut.

TABEL 2

\begin{tabular}{cccc}
\hline Nilai & $\begin{array}{c}\text { Jumlah } \\
\text { Siswa }\end{array}$ & Pencapaian & Persentase \\
\hline $\mathbf{0}-\mathbf{3 9 , 9}$ & 0 & Tidak tuntas & $0 \%$ \\
$\mathbf{4 0 , 0}-\mathbf{5 4 , 9}$ & 0 & Tidak tuntas & $0 \%$ \\
$\mathbf{5 5 , 0}-\mathbf{6 9 , 9}$ & 4 & Tidak tuntas & $19,05 \%$ \\
$\mathbf{7 0 , 0}-\mathbf{8 4 , 5}$ & 11 & Tuntas & $52,38 \%$ \\
$\mathbf{8 5 , 0}-\mathbf{1 0 0}$ & 6 & Tuntas & $28,57 \%$ \\
Jumlah & $\mathbf{2 1}$ & & $\mathbf{1 0 0 \%}$ \\
\hline
\end{tabular}

\section{Pembahasan}

a. Hasil Keterampilan Guru dalam Merencanakan Proses Pembelajaran Menulis Paragraf Argumentasi Menggunakan Model Cooperative Think Pair Share Siklus I dan Siklus II

Berdasarkan hasil dari perencanaan guru pada siklus I mencapai persentse $72,63 \%$ dengan kategori baik dan siklus II mencapai persentase $83,15 \%$ dengan kategori sangat baik mengalami peningkatan sebesar 10,52\%.

b. Hasil Keterampilan Guru dalam Melaksanakan Proses Pembelajaran Menulis Paragraf Argumentasi Menggunakan Model Cooperative Think Pair Share Siklus I dan Siklus II

Berdasarkan hasil pelaksanaan guru dalam proses pembelajaran pada siklus I pertemuan pertama mencapai $77,6 \%$ dengan kategori baik, selanjutnya pada pertemuan kedua mencapai $75,45 \%$ dengan kategori baik. Siklus II pertemuan pertama mencapai $84,8 \%$ dengan kategori baik, selanjutnya pada pertemuan kedua mencapai $83,63 \%$ dengan kategori baik.

c. Hasil Pembelajaran Menulis Paragraf Argumentasi Menggunakan Model Cooperative Think Pair Share Siklus I dan Siklus II

Pada siklus I rata-rata siswa 67,38 dan pada siklus II mencapai 74,28 mengalami peningkatan sebesar $6,9 \%$. Sedangkan persentase ketuntasan siswa pada siklus I mencapai $66,66 \%$ dan pada siklus II mencapai $80,95 \%$ mengalami peningkatan sebesar $14,29 \%$.

d. Penilaian Aktivitas Siswa Pada Proses Pembelajaran Menulis Paragraf Argumentasi Menggunakan Model Cooperative Think Pair Share Siklus I dan Siklus II
Pengamatan aktivitas siswa dalam proses pembelajaran menulis paragraf argumentasi menggunakan model cooperative think pair share mengalami peningkatan pada siklus I dan II. Penjelasan secara rinci dapat dilihat dalam tabel 3 sebagai berikut.

TABEL 3

\begin{tabular}{ccccc}
\hline No & $\begin{array}{c}\text { Aspek yang } \\
\text { diamati }\end{array}$ & $\begin{array}{c}\text { Siklus } \\
\mathbf{1}\end{array}$ & $\begin{array}{c}\text { Siklus } \\
\mathbf{2}\end{array}$ & Peningkatan \\
\hline $\mathbf{1}$ & $\begin{array}{c}\text { Aktivitas siswa } \\
\text { dalam proses } \\
\text { pembelajaran }\end{array}$ & $76,19 \%$ & $80,95 \%$ & $4,76 \%$ \\
& & & & \\
\hline
\end{tabular}

e. Penilaian Sikap Siswa Pada Proses Pembelajaran Menulis Paragraf Argumentasi Menggunakan Model Cooperative Think Pair Share Siklus I dan Siklus II

Persentase siswa sangat baik dalam kegiatan pembelajaran siklus $16,34 \%$ dan meningkat pada siklus 2 menjadi 7,94\%, persentase baik pada siklus 1 $47,61 \%$ dan meningkat pada siklus 2 menjadi 50,79\%, persentase cukup baik pada siklus $134,92 \%$ dan pada siklus 2 menjadi $34,92 \%$, dan persentase kurang baik pada siklus $111,11 \%$ dan menurun siklus 2 menjadi $6,34 \%$.

\section{IV.SIMPULAN DAN SARAN}

\section{SIMPULAN}

Berdasarkan hasil penelitian yang dilakukan peneliti di SMA Negeri 5 Singkawang keterampilan siswa dalam menulis paragraf argumentasi, dapat disimpulkan bahwa dalam penelitian ini mengalami peningkatan disetiap siklusnya, dibuktikan dengan beberapa hal diantaranya sebagai berikut. (1) Perencanaan pembelajaran pada siklus I mencapai $72,63 \%$ dan pada siklus II mencapai $83,15 \%$ mengalami peningkatan sebesar $10,52 \%$. (2) Pelaksanaan pembelajaran pada siklus I mencapai $76,59 \%$ dengan kategori baik dan pada siklus II mencapai $84,25 \%$ dengan kategori baik mengalami peningkatan sebesar 7,66\%. (3) Hasil Pada siklus I rata-rata siswa 67,38 dan pada siklus II mencapai 74,28 mengalami peningkatan sebesar 6,9\%. Sedangkan persentase ketuntasan siswa pada siklus I mencapai $66,66 \%$ dan pada siklus II mencapai $80,95 \%$ mengalami peningkatan sebesar 14,29\%.

\section{SARAN}

Saran yang disampaikan peneliti berdasarkan hasil penelitian sebagai berikut. (1) Perencanaan pembelajaran yang dibuat hendaknya disusun sesuai dengan tuntunan kurikulum dengan memperhatikan aspek-aspek diantranya, bahan pembelajaran, strategi atau model pembelajaran, media dan sumber belajar, evaluasi sehingga tujuan pembelajaran dapat tercapai, (2) Pada proses pelaksanaan pembelajaran bahasa Indonesia hendaknya guru tidak mengabaikan media atau sumber belajar yang dapat memudahkan pemahaman siswa terhadap konsep yang disampaikan oleh guru, (3) Guru hendaknya selalu berusaha 
meningkatkan pengetahuan dan kemampuannya dalam proses belajar mengajar menggunakan strategi pembelajaran yang tepat, inovatif, menarik, baik dari segi metode, pendekatan, dan rancangan, sehingga proses dan hasil pembelajaran sesuai dengan tujuan yang diharapkan, (4) Sebaiknya siswa dapat bekerja sama dalam proses pelaksanaan kegiatan pembelajaran dengan menggunakan model cooperative think pair share.

\section{DAFTAR PUSTAKA}

[1] Akhadiah, Sabarti dkk. 1997.Pembinaan Kemampuan Menulis Bahasa Indonesia.Jakarta:Erlangga.

[2] Arikunto, Suharsimi dkk. 2014. Penelitian Tindakan Kelas. Jakarta: Bumi Aksara.

[3] Dalman. 2015. Keterampilan Menulis. Jakarta: PT. Raja Grafindo Persada

[4] Daryanto dan Muljo Rahardjo. 2012. Model Pembelajaran Inovatif. Yogyakarta: Gava Media.

[5] Eti, Nunung Yuli. 2009. Paragraf. Klaten: Intan Pariwara.

[6] Gie, The Liang. 2002. Terampil Mengarang. Yogyakarta: Andi

[7] Nurgiyantoro, Burhan.2001.Penelitian dalam Pengajaran Bahasa dan Sastra.Yogyakarta:BPFE

[8] Purnama, Risma. 2014. Cooperative Learning. Pontianak: STAIN Pontianak Press.

[9] Suriamiharja, A. dkk. (1997). Petunjuk Praktis Menulis. Departemen Pendidikan dan Kebudayaan Direktorat Jendral Pendidikan Dasar dan Menengah Bagian Proyek Penataran Guru SLTP Setara D-III.

[10] Tarigan, Henry Guntur. 2008. Menulis Sebagai Suatu Keterampilan Berbahasa. Bandung: Angkasa Bandung. 